\title{
Identificando o Transtorno Bipolar
}

\author{
Autora: Isabela Balconi Sydow \\ Orientador: Prof. Dr. Adauto Locatelli Taufer
}

Resumo: Esta comunicação é o produto de uma atividade de pesquisa, desenvolvida pelos alunos de $7^{\mathrm{a}}$ e $8^{\mathrm{a}}$ Série do Ensino Fundamental do Colégio de Aplicação da UFRGS, denominada Projeto Pixel. Apresentam-se, aqui, alguns resultados encontrados neste processo de investigação sobre a bipolaridade: transtorno efetivo, cujo portador oscila entre fases de agitação e depressão. Esses estágios se manifestam de duas formas: a maníaca e a depressiva. Nesta, notam-se a baixa da autoestima, a sensação de cansaço constante e a dificuldade de manter a atenção. Naquela, percebem-se estados de extrema agitação. As causas da bipolaridade têm sido investigadas, porém acreditase que a genética e os fatores cotidianos contribuem para o seu desenvolvimento. Sua identificação normalmente é realizada por pessoas que convivem com portadores deste transtorno. Porém, o diagnóstico somente deve ser feito por um médico qualificado. Foram identificados dois tipos de bipolaridade: Tipo I, (psicose maníaco-depressiva), em que o paciente alterna entre as fases maníaca e depressiva; Tipo II, que não apresenta episódios maníacos, e sim de hipomania conjunta de depressão. A bipolaridade pode iniciar em qualquer fase da vida. Além disso, não existem exames que auxiliem os médicos a diagnosticarem este mal. Durante a realização da pesquisa, foi difícil obter acesso a informações esclarecedoras, pois muitas fontes consultadas apresentavam dados contraditórios. Por isso, entrevistas com psiquiatras e psicólogos foram muito importantes para a concretização deste projeto.

Palavras-chave: Comportamento; Pesquisa; Projeto Pixel; Transtorno Bipolar. 